Author: A H Benjamin

\title{
PAYMENT FOR ECOSYSTEM SERVICES
}

\section{ISSN 1727-3781}

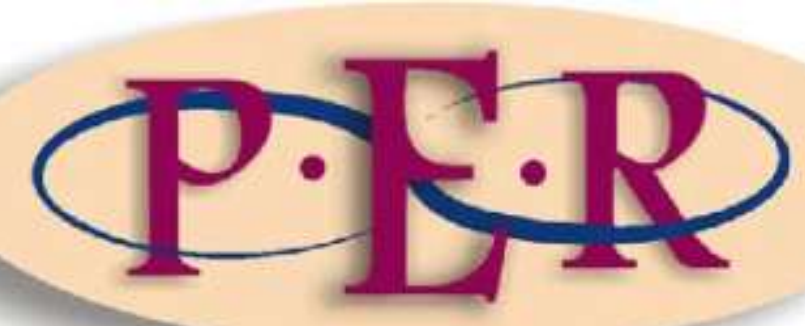

2013 VOLUME 16 No 2

http://dx.doi.org/10.4314/pelj.v16i2.1 


\section{PAYMENT FOR ECOSYSTEM SERVICES}

\section{A H Benjamin*}

Ladies and Gentlemen,

I am delighted to speak on the theme of this workshop that I find most relevant to the development of environmental law around the world. Indeed, Payments for Ecosystem Services (PES) can be seen as one of the most important issues in environmental law nowadays. It is a topic that is still emerging and frankly not well explored by the legal scholarship. In this introductory speech, I will focus on the legislative design for PES since, as we speak, most countries do not have specific legislation that addresses the subject. Brazil for instance is in the process of drafting its national legislation on Ecosystem Services and there are several important issues that can be raised from this experience.

\section{What are Ecosystem Services?}

In a new area of law, and in this case in a new area of environmental law, the first aspect to be addressed is the definition of what we have in mind. This means that legislators will have to define the concept of Ecosystem Services (ES), with the contribution of lawyers and environmental law scholars.

So, what are ES? Environmental scientists might have their view of what ES represent from the scientific perspective, but this is not what we will focus on here.

Antonio Herman Benjamin, LLB (Universidade Federal do Rio de Janeiro); LLM (University of Illinois), PhD (Universidade Federal do Rio Grande do Sul). Justice, High Court of Brazil (Superior Tribunal de Justiça) Brasília, Brazil. Chair, IUCN Commission for Environmental Law. Founding president of the Brazilian Consumer Law and Policy Institute and the Law for a Green Planet Institute. Visiting Professor at the University of Texas School of Law. Chair of the Brazil-U.S. Law Society and co-president of INECE (International Network for Environmental Compliance and Enforcement). Member of the UN Secretary General Legal Expert Groups on Crimes against the Environment, and CONAMA, the National Environmental Council of Brazil. He is emeritus editorin-chief of the Brazilian Consumer Law Review and the Brazilian Environmental Law Review. Email: planet-ben@uol.com.br. 
It is according to legal constructions that we will be able to reach some sort of agreement on the definition of ES and that we will be able to make sure that this definition does not conflict with existing legislation and with the other environmental problems that we face.

It is also important to define one word within the expression PES, which is the word payment. To do this we need to answer the following four questions: Payments to whom? Payments for what? On what basis? And for how much?

\section{The basis for payments}

Let's start with the basis. What are the constitutional constraints or the constitutional formulations at the national level (for example in Brazil or South Africa) that any legislative effort to define and organise the payment of ES will have to respect? Many countries already have clear constitutional provisions either alluding to or including a definition of the environment or of natural resources (e.g. the constitutional language addressing genetic resources). In including such language within their text, those constitutions have often addressed issues of ownership. In a number of countries water and even watersheds, for example, are considered State property.

I am referring to the constitution as the basis for payments since these fundamental issues related to the environment should be addressed not by a statute but by a constitutional provision, since any law passed by Parliament will have to be examined for legality in the light of the provisions of the constitution already in place.

\section{To whom should the payments be made?}

Based on the definition of ES, we need to address to whom any payment has to be made. The constitutions that I have compared do not use the terminology of ES, but there are constitutional provisions which allude to essential ecological processes, which is a concept not far from ES. If a constitution already recognises state or public ownership of such ecological processes, then it will be complicated to assess 
PES and to privatise those payments. Indeed, if the State owns the essential ecological processes, how can we justify the payment for such processes to private individuals? It seems that the decision will be based not on ownership but rather on people's level of management of those natural ecosystems. (For instance, in managing those ecosystems indigenous and local communities (ILCS) often end up protecting those components of nature that we want to secure.) Of course, it is easier to recognise payments to private individuals for ES if the constitution does not recognise public or state ownership of those natural resources. However, it is also important to stress that sometimes, even when those constitutional provisions recognise the private ownership of natural resources, the constitution might say (and some constitutions do) that the intangible aspects of natural resources, the socalled ecological processes, belong to everyone, meaning to all of the citizens of a particular country.

\section{Payments for which services?}

The other question that parliamentarians will have to address when working on PES is to determine what the payment will be for. Is a PES a payment for not doing what the legal system allows the person to do? Or is it payment for not violating the obligations that are imposed on private owners in accordance with the Constitution and the laws put in place? Determining what the payment will be for is an important question because the risk is that we may end up paying for people to comply with legal requirements that are in fact applicable to everyone. This would mean that at end of the day, instead of strengthening compliance, there will be an incentive for people to pretend not to comply, or to threaten not to comply with the law in order to be paid for conserving nature while actually doing what the legislation in place already requires.

\section{How much should be paid?}

Finally, there is the issue of how much to pay, and it is even more than that since it has to do not just with the amount to be paid but also with the nature of the payment. Is this a direct payment (in Dollars, Real, Euros or other currencies) that will be given to those that are eligible for that payment? Or do we envision 
payments that can better protect the environment as we want it to be, for example through tax incentives or subsidized credits?

It is a fascinating and a necessary topic to explore. We know that traditional command-and-control models for protecting the environment have not succeeded as well as we wanted them to. However, they have not failed either. We therefore need to complement the systems that are in place while at the same time recognising that there are difficulties; technical difficulties, but also difficulties in harmonizing a new concept with a system that has been in place for not more than 40 years.

I will end with one example in which we will see that, depending on the way in which we draft any statute in respect to PES, we may inadvertently cause tragic collateral damage to nature as we attempt to protect it. Think in terms of Protected Areas: governments are required to pay compensation to property owners when they expropriate land in order to establish Protected Areas like national parks, reserves, national forests and so on. If the land is private, the State has to pay compensation. We pretty much know how to assess this type of payment: look at the market value for that type of property, and that's the amount that the government will have to pay as compensation. If we add to that an amount of compensation for the intangible ES, depending on how we do it, we might end up with a bill that will be so high and which will make it so expensive for governments to expropriate land in order to protect a critically endangered species, that governments, especially in periods of economic crisis, will hesitate to do so and will eventually not even consider taking those direct actions to protect nature. 